Annales Missiologici Posnanienses t. 20 (2015), s. 137-149

DOI: $10.14746 / \mathrm{amp} .2015 .20 .9$

JERZY DUDA

Wyższe Seminarium Duchowne im. Jana Pawła II w Siedlcach / John Paul II Major Seminary in Siedlce

\title{
Prawda jako fundament nauczania misyjnego w Protreptikos Klemensa Aleksandryjskiego
}

Scholarcha Tytus Flawiusz Klemens należy z pewnością do najoryginalniejszych pisarzy antyku chrześcijańskiego. Campenhausen z właściwą sobie dozą emfazy określa go jako „mistrza dyskusji”, „odwiecznego literata”, „bohemistę o wykształceniu akademickim” (Campenhausen 28). Jego własne doświadczenia związane z poszukiwaniem mądrości i Boga, pasja intelektualna oraz praktyka katechetyczna zaowocowały w szerokiej działalności literackiej (Eusebius Caesariensis 94, 104). Wśród zachowanych do dnia dzisiejszego utworów na szczególną uwagę zasługuje Protreptikos. Stanowi on wraz z Paidagogos i Stromateis pierwszą część swoistej „trylogii” opisującej proces chrześcijańskiej paidei mającej za zadanie pomóc czytelnikowi odkryć drogę do prawdy, wiary i doskonałej miłości (Chadwick 92-97; Drączkowski 56-64; Wytzes 146-158). Mimo iż we współczesnej literaturze patrystycznej dzieło to niekiedy bywa określane mianem apologii (Żurek 71), jednak bardziej adekwatne wydaje się nazwanie go terminem zaczerpniętym z tytułu tego pisma: protreptikos bądź w thumaczeniu jako zachęta, pobudzenie. Protreptikos należy bowiem do znanego w starożytności gatunku literatury dydaktycznej, wykorzystywanego m.in. w środowisku filozoficznym w formie mowy czy dialogu, gdzie za pomocą określonego sposobu argumentacji zachęcano czytelników do podjęcia wysiłku w celu doskonalenia moralnego i intelektualnego. Można więc z całą pewnością powiedzieć, że Klemens Aleksandryjski, pisząc ten utwór, świadomie posłużył się klasycznym protreptikosem nawiązującym z pewnością do Zachęty do filozofii Arystotelesa czy też Hortencjusza Cycerona, nadając mu jednak specyficznie chrześcijański charakter (Sołowianiuk 102-103). Protreptikos Scholarchy Aleksandryjskiego jest bowiem misyjnym i propagandowym traktatem mającym pobudzić czytelnika do refleksji nad 
swoim życiem, otaczającą go rzeczywistością oraz doprowadzić do odkrycia Boga, który objawia się w osobie Logosu - Jezusa Chrystusa (Wyrwa 152). Celem podjętych przez nas badań jest ukazanie charakterystycznego i dość oryginalnego w owym czasie w Kościele sposobu oraz metody przepowiadania kerygmatycznego. Klemens Aleksandryjski oparł go na ukazaniu prawdy. Jest ona dla niego fundamentem w nauczaniu misyjnym, gdyż dzięki niej człowiek ma szansę odkryć jej źródło w Bogu.

\section{Koncepcja poznania prawdy}

Problematyka prawdy oraz próba metodycznej analizy tego pojęcia należała do głównych tematów podejmowanych przez antyczne środowiska filozoficzne (Judycki 25-62). Klemens Aleksandryjski doskonale obeznany z intelektualną myślą grecką oraz współczesną mu sytuacją społeczno-religijną wykorzystał to zagadnienie i - akomodując je na płaszczyźnie teologicznej - zbudował na nim eudajmonistyczną koncepcję poznania prawdy prowadzącej ostatecznie ku Bogu. Według niego: „Prawda nie jest trudno dostępna, nie jest też niemożliwa do osiągnięcia. Ona przebywa bardzo blisko nas, mieszka w nas samych [...]" (Clemens Alexandrinus 177).

Tego typu stwierdzenie ukazuje krańcowo inną koncepcję postrzegania rzeczywistości prawdy niż ta, która była reprezentowana przez pogańskie środowisko helleńskie. Grecy, według Scholarchy z Aleksandrii, ulegli błędowi, pogrążyli się w ciemności i uznali, że oblicze prawdy jest zwodnicze i dostrzegalne jedynie dla niektórych (Clemens Alexandrinus 53). Nie można jej w pełni dostrzec czy też nią się całkowicie zachwycić. Ona ukryła się przed światem, łudząc mirażami, i odsłania jedynie pewne swe aspekty tym, którym sama zechce je objawić. Chociaż człowiek ma przeczucie istnienia prawdy, to jednak pozostaje bezsilny w swoim dążeniu do jej poznania. Dlatego też, jak twierdził Klemens, w myśli helleńskiej bardzo często, mówiąc o prawdzie, posługiwano się mitem, zaś za najodpowiedniejsze miejsce jego interpretacji uznano środowisko religijne (Clemens Alexandrinus 82-83, 138). W tym kontekście pojawiło się jego pytanie o myśl filozoficzną i jej rolę w procesie odkrycia prawdy. Klemens Aleksandryjski, o czym powiemy dokładniej w dalszej części pracy, wyraził przekonanie, że filozofia nie jest w tej kwestii miarodajna i często sama tworzy zabobon (Clemens Alexandrinus 122-123). Zaślepiona bowiem przez próżność własnych poszukiwań intelektualnych koncentruje się generalnie na stworzeniu, nie zaś na Stwórcy (Clemens Alexandrinus 126-127). Szukając prazasady w rzeczywistości materialnej czy też ubóstwiając nadprzyrodzone siły, dopuszcza się błędu w założeniach. Świat stworzony mówi o prawdzie, lecz nie stanowi jej istoty, a jedynie odblask. 
Można więc powiedzieć, że poznanie filozoficzne charakteryzuje się pewną właściwą intuicją, lecz prawdę „widzi niejako we śnie” (Clemens Alexandrinus 128). Samo zaś szczątkowe poznanie czy też propagowanie błędu sprawia, że człowiek, potomek nieba, szuka jej źródła nie tam, gdzie powinien. Dlatego też Klemens, mając na uwadze własne życiowe doświadczenia, uważał za swoją powinność i misję objawić prawdę. Z właściwym sobie entuzjazmem i patosem mówił o tym w sposób następujący:

Sprowadźmy więc z niebios Prawdę razem z całkowicie objawiającą się mądrością oraz święty chór proroków na świętą górę Boga. Prawda zaś, rozsiewająca daleko promienie, niech je skupi wobec tych, którzy pogrążają się w ciemnościach i niech wydobędzie ludzi od błędu, niech im poda swoją najsilniejszą prawicę, rękojmię zbawienia. Oni zaś, gdy zwrócą wzrok ku górze i przejrzą, niech porzucą Helikon i Kitajron i niech zamieszkają na Syjonie (Clemens Alexandrinus 54).

Warto w tym miejscu zauważyć, że Aleksandryjczyk od samego początku Protreptikosa starał się bazować na nomenklaturze będącej niejako pomostem między semantyką religijno-kulturową świata pogańskiego a chrześcijaństwem. Potwierdzeniem tego jest powyższy cytat. Klemens, mówiąc o prawdzie, odwołał się w głównej mierze do dwóch metafor. Pierwszą z nich jest obraz góry. Antyczni Grecy uważali, że odkrycie prawdy należącej do rzeczywistości mistycznej potrzebuje stosownego wtajemniczenia. Sprzyjać temu miały nie tylko obrzędy religijne o charakterze misteryjnym i przekazywana w nich wiedza, ale również pewne szczególne miejsca. Zaliczano do nich góry. One to od najdawniejszych czasów stanowiły obraz spotkania dwóch rzeczywistości: ludzkiej i boskiej. To tam zanoszono modlitwy, składano ofiary, budowano świątynie. Leżący w Beocji, a wspomniany przez Klemensa w Protreptikosie, masyw górski Kitajron wiązano z kultem Zeusa i Apollona. Na jego wzgórzach pokrytych świętymi lasami odbywały się orgiastyczne uroczystości ku czci Dionizosa oraz wtajemniczenia w kulty pogańskie. To tam, według tragedii Eurypidesa, bachantki doprowadzone przez Dionizosa do mistycznej ekstazy i szaleństwa dopuściły się zabójstwa tebańskiego króla Penteusza. Scholarcha z Aleksandrii, nawiązując do tej tragedii, mówił, że Kitajron jest miejscem fałszywym. To nie na tych górach sprawowane są święte obrzędy prawdy (Clemens Alexandrinus 188-189). Również inne opiewane w greckich hymnach góry Odrysów, Traków czy też masyw Helikon, związany z kultem Apollona i siedzibą Muz, są miejscem fałszywych wtajemniczeń (Clemens Alexandrinus 53-54). Żadne pogańskie obrzędy, mimo ich modłów, ekstatycznych misteriów i inicjacji, nie odkryją prawdy, gdyż za nimi stoi jej przeciwnik, wąż, który zwodzi ludzi (Clemens Alexandrinus 77). Fałszywa pobożność nie ma bowiem nic wspólnego z Bożym kultem, a jedynie tworzy 
zabobon (Clemens Alexandrinus 78). Misteria pogańskie są oszustwem Szatana, który dzięki nim pragnie omamić człowieka pozorami pobożności, splugawić jego godność przez niemoralne czyny i ostatecznie uzurpować sobie cześć boską. Jest tylko jedna góra umiłowana przez Boga, gdzie sprawowane są święte obrzędy (Clemens Alexandrinus 188-189). Jest nią Syjon opromieniony obecnością prawdy (Clemens Alexandrinus 54). Góra, na której wznosiła się świątynia jerozolimska, stała się dla Klemensa symbolem mieszkania Boga, ale też miejscem, gdzie prawda objawia swą mądrość. Triumfująca na Syjonie prawda jest synonimem Logosu, który jako wieczny, jedyny kapłan Boga wszechmocnego sprawuje tam święte obrzędy (Clemens Alexandrinus 190). Uczestniczą w nich chóry sprawiedliwych, córki Boga, święci, aniołowie i prorocy. To tam wieczny Jezus prosi za całym rodzajem ludzkim: barbarzyńcami oraz Grekami, by porzucili dawne życie i weszli na drogę do Syjonu - nieba (Clemens Alexandrinus 191). Zdobycie tej góry związane jest $\mathrm{z}$ wysiłkiem poszukującego. Konieczne jest w tym wypadku porzucenie Kitajronu i Helikonu, odcięcie się od zwodniczych nauk oraz zawierzenie mocy Tego, który daje rękojmię zbawienia (Clemens Alexandrinus 54). On umocni dążących ku prawdzie i sam przeniesie ich z ziemi upadku do nieba swej chwały (Clemens Alexandrinus 182-183).

Drugą z metafor, do której często odwoływał się Klemens w kontekście nauki o prawdzie, jest obraz słońca. Prawda należąca do rzeczywistości nadprzyrodzonej jest przyrównana do słońca wznoszącego się na niebiosach, które rozlewa swoje promienie na ziemię i daje jej życie. Jest tutaj zawarta myśl, że źródło prawdy nie jest związane ze światem ziemskim. Prawda w swej istocie należy do rzeczywistości, która wykracza poza ziemską materię, jednakże nieprzerwanie emanuje swoim blaskiem i światłem. Aleksandryjczyk był świadomy tego, że metafora słońca może być opacznie interpretowana przez środowiska pogańskie, dlatego też doprecyzował ów obraz, zdecydowanie odrzucając jego wszelkie konotacje materialistyczne. Mówiąc o pewnych ziarnach prawdy wskazujących na Boga, które można znaleźć w pismach helleńskich mędrców i poetów, przywołał myśl Meandra wzywającego do czci słońca (Clemens Alexandrinus 133-134). Ten wybitny przedstawiciel greckiej komedii wyraził przekonanie, że słońce jest najwyższym z bogów i dzięki niemu można poznać ich panteon, a przez to również lepiej zrozumieć nasz własny świat oraz człowieka. Dla Klemensa tego typu stwierdzenie było nie do przyjęcia. Jednak, mając na uwadze szacunek, jakim darzyli współcześni mu poganie oraz liczni chrześcijanie literaturę klasyczną, nadał temu stwierdzeniu nową interpretację. Sugerował, że w kwestii poznania prawdziwego Boga człowiek musi przejść z płaszczyzny materialnej na tę związaną z doświadczeniem duchowym. Słońce, które widzimy na niebie, należy do rzeczywistości świata stworzonego, a zatem explicite ani nie może być Bogiem, ani go w pełni nie objawia. Jest 
w stanie to uczynić jedynie Logos, który jest prawdziwym „słońcem duszy” (Clemens Alexandrinus 133-134). Wschodząc w niej, jak słońce o poranku, Zbawiciel rozlewa światło czystsze niż to na niebie i dzięki niemu człowiek może doświadczyć autentycznego oświecenia (Clemens Alexandrinus 182).

Scholarcha z Aleksandrii był świadom tego, że ludzie przez swoje odejście od Boga pogrążają się w mrokach błędu (Clemens Alexandrinus 54). Uważał, że ciemność, w jakiej żyją, ograniczyła ich zdolności poznawcze, zaś grzechy, którym się oddali, związały ich z ziemią. Zachód bowiem objął świat w posiadanie (Clemens Alexandrinus 182-183). Przyzwyczajenie do zła, niewiedza i grzeszne życie zdeprawowały naturalną skłonność człowieka ku dobru. To doprowadziło do swego rodzaju degradacji natury ludzkiej. Klemens wiązał ów stan z prehistorycznym grzechem pierwszych ludzi. To już wtedy błędne poglądy sprawiły, że człowiek zszedł z drogi prawdy. One przyczyniły się do jego zguby. „Człowieka - potomka nieba - odciągnęły od życia niebiańskiego i osadziły go na ziemi oraz skłoniły do związania się z ziemskimi stworzeniami" (Clemens Alexandrinus 80).

Ludzie pogrążeni w pożądliwości ciała ulegli ułudzie tego świata, do którego zostali strąceni (Clemens Alexandrinus 184). Zapomnieli, że pochodzą z nieba i tam jest ich dom. Stali się jak niewidomi. Klemens Aleksandryjski, mówiąc o ciemności, która dotknęła świat ludzi po grzechu, nawiązał do greckiego mitu o tebańskim wieszczu Terezjaszu, synu Euresa i Chariklo, który za swoje winy względem bogów został skazany na ślepotę (Clemens Alexandrinus 189). Według podania, gdy Epigoni zdobyli Teby, Terezjasz opuścił miasto i udał się na wygnanie. Klemens widział w nim archetyp współczesnych mu pogan. Wzywał ich, by porzucili swoje dawne życie, gdzie trwali w ciemności swego kalectwa i służyli własnym namiętnościom. Żyjąc w świecie, symbolizowanym w micie przez Teby, nie są w stanie poznać prawdy. Dzięki Chrystusowi mogą odzyskać wzrok. On ma moc uzdrowić ich ślepotę. Muszą jednak porzucić Teby, gdzie czeka ich zguba. Dzięki prawdziwemu światłu Jezusa Chrystusa minie noc, która spowija ich życie, i oddali się śmierć, a ludzie na nowo ujrzą niebo. To będzie dla nich źródłem szczęścia. Klemens wykorzystał mit o Terezjaszu, by również omówić znaczenie i rolę Kościoła w procesie poznania prawdy. Terezjasz, mimo iż jest wieszczem i ma zdolność jasnowidzenia, nie jest w stanie dotrzeć do źródła prawdy. Doświadcza jedynie jej przebłysków. Potrzebuje osoby, która będzie przy nim, by go wesprzeć i poprowadzić właściwą drogą ku uzdrowieniu. Mimo iż Aleksandryjczyk nie używał w tym kontekście nominalnie terminu Kościół, to jednak mówił o jego zasadniczej roli w procesie nauczania i wtajemniczenia w zbawcze misteria. To dzięki niemu dokonuje się oświecenie, a uczeń Chrystusa zostaje opieczętowany znakiem zbawienia (Clemens Alexandrinus 189-190). Święte misteria Kościoła sprawiają, że mija ślepota i człowiek otrzymuje zdolność widzenia Boga. 
Scholarcha z Aleksandrii uważał, że mimo pierwotnego upadku i osłabienia więzi z nadprzyrodzoną rzeczywistością świata Bożego istnieje ciągle między człowiekiem a niebem przedziwna łączność (Clemens Alexandrinus 80). Chociaż została ona w jakiś sposób naruszona przez grzech i przyćmiona przez niewiedzę, to jednak jest na tyle silna, by ciągle rodzić pragnienie dobra i tęsknotę za szczęściem, a oczy na nowo kierować ku niebu, przypominając tym samym, gdzie jest nasz dom. Dla lepszego zobrazowania takiego stanu ducha Klemens posłużył się klasycznym przykładem Odyseusza (Clemens Alexandrinus 153). Ten sławny bohater wojny trojańskiej przez siedem lat był trzymany jako zakładnik przez nimfę Kalipso na wyspie Ogygii. Kalipso pragnęła, by Odyseusz zapomniał o swojej Itace i został jej mężem. Próbowała go oczarować swoją pięknością, namiętnością i pochlebstwami. „Starzec z Itaki” nie dał się jednak jej zwieść i zawsze marzył o powrocie do swojej ojczyzny (Clemens Alexandrinus 153). Aleksandryjczyk, interpretując w duchu chrześcijańskim jego postawę, zauważył, że mimo wewnętrznego przeczucia o niestosowności i przypadkowości miejsca naszego obecnego przebywania na tym świecie część ludzi tęskni nie za swoim prawdziwym domem, a jedynie za jego ułudą. Podobnie jak Odyseusz marzył o tym, by dojrzeć choć dym ze swojej Itaki, tracąc powoli nadzieję na uwolnienie i zmianę swojej sytuacji, tak niektórzy poganie zapominają, że mogą odwrócić się ich losy i nie tylko wyobrażenia, a sama prawda może być ich udziałem. Są bowiem siły, podobne do mitycznej nimfy Kalipso, którym zależy na zachowaniu status quo i związaniu człowieka z jego ziemią niewoli. Należą do nich złe duchy i demony. One walczą o to, byśmy nie zostali oświeceni. Człowiek bowiem, bez Bożego światła, nie różni się od „tuczonego drobiu”, hodowanego w ciemności i „karmionego na rzeź" (Clemens Alexandrinus 181). Trwanie więc w ciemności jest zwycięstwem zła, a tragedią tego świata. Ciemność, jak gęsta mgła, osłoniła ludzi przed prawdą i stworzyła rzeczywistość, w której czują się ciągle jak w niewoli (Clemens Alexandrinus 182). Nie jest to świat, o którym ludzie marzyli i za którym podświadomie tęsknią. Człowiek jest w nim ograniczony i zagubiony. Żyje jak kret pod ziemią (Clemens Alexandrinus 184), w ciągłej ciemności i ze świadomością własnej ułomności. Myśli tylko o tym, by zdobyć minimum do przetrwania. Jest dotknięty ślepotą, a to sprawia, że nie widzi już nieba ani jego Stwórcy. Kalectwo ślepoty często połączone jest z głuchotą, która nie pozwala mu usłyszeć słów prawdy. Konieczne jest więc duchowe przebudzenie, uzdrowienie i wydobycie się z tego stanu (Clemens Alexandrinus 151). Człowiek, jak sądzi Scholarcha z Aleksandrii, nie jest w stanie sam sobie pomóc. Jego dążenie i poszukiwania prawdy często przypominają szukanie po omacku. Potrzebuje więc Zbawiciela. Dlatego też sam Bóg posłał nam odwieczne Słowo prawdy. Jest ono jak słońce, które rozprasza ciemności. Od Jego przyjścia na ziemię rozpoczęła się nowa historia świata, czas oświecenia, „Zachód zwrócił 
się ku wschodowi” (Clemens Alexandrinus 182). Nadszedł kres nocy niewiedzy i błędu. Ciemność ustępuje wraz z pierwszymi promieniami wschodzącego słońca sprawiedliwości. Rozpoczyna się dzień Pana. Jego słońce wschodzi nad wszystkimi ludźmi. Nie jest ono darem jedynie dla wybranych. To światło niesie życie dla tych, którzy w nim uczestniczą i dzięki niemu doświadczają poznania prawdy. Scholarcha z Aleksandrii pisze o tym w sposób następujący: „On budzi ze snu i każe błądzącym dźwignąć się z ciemności. «Zbudź się, o śpiący - mówi - i powstań z martwych, a zajaśnieje ci Chrystus», Słońce zmartwychwstania, Ten, «który przed jutrzenką został zrodzony» i życie daje poprzez swoje promienie" (Clemens Alexandrinus 151).

Chrystus jest tym, który wieńczy proces poznania prawdy. Swoją nauką oświeca jaśniej niż słońce. Budzi tych, którzy są pogrążeni we śnie, przebóstwia człowieka swoją nauką i ofiaruje mu światło, dzięki któremu może on dostrzec Boga (Clemens Alexandrinus 181). Dokonuje się to już teraz na ziemi dzięki świętym misteriom sprawowanym w społeczności Kościoła. Dzięki nim wtajemniczony otrzymuje oświecenie i pieczęć, która „ucznia światła”, „przyjaciela i współdziedzica Chrystusa” zachowa na życie wieczne (Clemens Alexandrinus 184). Kulminacją zaś tego procesu będzie pełne ostateczne zjednoczenie Boga i Jego przyjaciela - człowieka w chwale nieśmiertelności nieba (Clemens Alexandrinus 190).

\section{Kerygmantyczny charakter nauczania o prawdzie}

Przedstawiona przez Klemensa Aleksandryjskiego w Protreptikosie koncepcja poznania prawdy była istotnym elementem swoistego na gruncie chrześcijańskim sposobu przepowiadania kerygmatycznego. Wnikliwa analiza tekstu prowadzi do wniosku, że utwór ten nie jest skierowany jedynie do wykształconych i wychowanych w tradycjach religijno-filozoficznych hellenizmu pogan (Żurek 70). Forma przekazu, jak również zastosowana argumentacja, oparta w znacznej mierze na Biblii i określonej myśli teologicznej, była wykorzystana jako paralelny sposób nauczania misyjnego zarówno niewierzących, neofitów, jak też należących już od dłuższego czasu do Kościoła chrześcijan, pragnących z jednej strony pogłębić swoją wiarę, z drugiej zaś skonfrontować ją ze współczesną tradycją kulturową (Sołowianiuk 103). Odkryta bowiem w nauce Chrystusa prawda pozwalała inaczej spojrzeć na Boga, świat, historię człowieka i jego powołanie. Utwór ten ma więc za zadanie zarówno zachęcić do wejścia do Kościoła tych, którzy są otwarci na prawdę, jak też do wyjścia członków Kościoła z enklawy separatyzmu wiary do świata kultury antycznej z przesłaniem Ewangelii. Według Klemensa Aleksandryjskiego idealną płaszczyzną porozumienia tych dwóch środowisk jest domena prawdy. Dlatego też 
posłużył się nią do ukazania wielorakich korzyści wynikających z jej odkrywania i kreowania życia według niej. Scholarcha z Aleksandrii zwraca uwagę na trzy fundamentalne domeny jej występowania. Należą do nich: świat natury, szeroko rozumiana kultura oraz objawienie. Trzeba tutaj zaznaczyć, że mimo intelektualnego rozróżnienia obszarów występowania prawdy są one ze sobą silnie związane. Zagadnienie dotyczące płaszczyzn występowania prawdy było przez Klemensa potraktowane dość ogólnie, niemniej jednak wydaje się ważne dla integralności podjętych badań przedstawienie również i tej tematyki.

\section{a) Świat natury}

Według Klemensa z Aleksandrii świat uczyniony z woli Boga zawiera w sobie samym prawdę o Stwórcy. W sposób szczególny daje się to zauważyć na płaszczyźnie harmonii, piękna i uporządkowania w świecie natury, które wskazują na genialną inteligencję Boskiego Architekta. Aleksandryjczyk mówi o tym w sposób następujący:

Bóg cały wszechświat harmonijnie uporządkował i różne elementy połączył w zgodne współbrzmienie, aby w ten sposób cały świat stał się jedną harmonią. Pozwolił morzu trwać w postaci płynnej, ale zabronił mu zalać ląd, natomiast poruszającą się dotychczas ziemię utwierdził $\mathrm{w}$ jednym miejscu i morze uczynił jej granicą. Żar ognia złagodził powietrzem, jak gdyby harmonię dorycką zmieszał z lidyjską, zimny powiew powietrza osłabił przez połączenie z ogniem, zestawiając w ten sposób melodyjnie przeciwstawne cechy wszechświata (Clemens Alexandrinus 57).

Świat natury, niczym doskonale zharmonizowana pieśń, rozbrzmiewa boską muzyką i zachwyca tych, którzy są wrażliwi na jej dźwięki. Jest ona piękniejsza niż najlepsze treny czy hymny ułożone przez kompozytorów (Clemens Alexandrinus 54). Jej dźwięki unoszą myśl ludzką ku boskiemu majestatowi i chwalą Jego mądrość oraz dobro. Ta pieśń obejmuje cały wszechświat. Jest to muzyka prawdy o świecie natury, który ma swe źródło w Bogu. To z Jego woli Boskie Słowo, pod natchnieniem Ducha Świętego, dokonało dzieła uporządkowania makro- i mikrokosmosu (Clemens Alexandrinus 58). Klemens, mówiąc o mikrokosmosie, ma na myśli człowieka i jego psychofizyczną naturę. Połączenie w nim elementu cielesnego i duchowego sprawia, że jest on otwarty zarówno na rzeczywistość materialną, jak również na prawdę wieczną. Zatem nie tylko martwa natura, lecz przede wszystkim człowiek, stworzony jako piękny instrument, ma rozbrzmiewać świętą muzyką ku Bożej chwale. 
Cały bowiem świat należy do Boga, zaś człowiek jest jego najpiękniejszą częścią (Clemens Alexandrinus 192).

Na kanwie nauki o odkrywaniu prawdy zawartej w świecie natury Aleksandryjczyk przedstawił swoistą teorię poznania. Uważa on, że tajemnica poznania prawdy o wszechświecie zawarta jest w Bogu. Ku Niemu więc winna skłaniać się nauka. Człowiek w swoich poszukiwaniach prawdy potrzebuje trwałego punktu odniesienia oraz odpowiednich narzędzi, które pozwolą mu precyzyjnie dokonać potrzebnych obliczeń. Obiektywną miarą prawdy o wszechświecie jest Bóg (Clemens Alexandrinus 134-135). On jeden jest prawdziwy i niezmienny. Bóg w swoim zamyśle stwórczym wszystko zmierzył i zważył. Jego sprawiedliwość obejmująca całą naturę wszechświata przypomina szale wagi, które nie przechylają się bez słusznej przyczyny na żadną ze stron. Zatem, poznając prawdę Bożą dotyczącą tajemnicy stworzenia, człowiek ma możność dzięki niej lepiej i obiektywniej zrozumieć świat natury oraz prawa nim rządzące.

\section{b) Kultura antyczna}

Rzeczywistość, w jakiej żyje człowiek na ziemi, oraz jego kondycja moralna dotknięta została konsekwencjami upadku (Clemens Alexandrinus 82). Według Klemensa Aleksandryjskiego genezy takiego stanu rzeczy należy szukać zarówno w słabości natury „potomków nieba”, jak również w błędach, jakich się oni dopuścili pod wpływem działania demonów (Clemens Alexandrinus 55). Winą ludzi jest to, że ubóstwili materię, czyniąc sobie z niej fałszywych bogów, zapominając przy tym o prawdziwym Stwórcy (Clemens Alexandrinus 120). Zło tego typu postępowania polega na tym, że stworzony przez ludzi kult pogański wpisany w kulturę antyczną zdeprawował obraz prawdziwego Boga. To, co święte, stało się szyderstwem, panteon bóstw karykaturą wiecznego nieba, ich moralność drwiną z prawdziwych wartości. Czystość została wypaczona niepohamowaną żądzą (Clemens Alexandrinus 110-111). Klemens uważa, że pod zasłoną mitologii greckiej ukrywa się świat demonów. To one cieszą się z szaleństwa ludzi praktykujących odrażające misteria i pragną ich zguby. Dlatego też człowiek potrzebuje prawdy, gdyż ona obnaża straszne maski tkwiące na twarzach fałszywych bogów oraz wykazuje absurdalność tego typu kultu (Clemens Alexandrinus 82-83).

Scholarcha z Aleksandrii genezę zabobonu wiąże z ludzkim grzechem i postępującą demoralizacją człowieka. Pokazuje na przykładach, jakimi motywami kierowali się twórcy błędu i jak rozszerzały się stworzone przez nich fałszywe misteria. Według niego początek stworzenia bogów należy wiązać z błędnymi poglądami, sztuką, występkiem oraz grzesznymi namiętnościa- 
mi (Clemens Alexandrinus 103). Odchodząc od prawdziwego Dobroczyńcy, ludzie stworzyli sobie Jego namiastkę, czcząc swoich ziemskich bohaterów: Dioskurów, Heraklesa, Asklepiosa (Clemens Alexandrinus 81-82). Doprowadziło to do sytuacji, w której wolny człowiek stał się niewolnikiem kultu stworzenia. Egipcjanie czcili nierozumne stworzenia, Persowie rzekę, Scytowie szablę, Arabowie kamień, zaś Grecy posągi z kamienia i drzewa (Clemens Alexandrinus 106-107). Ich kult zafałszował prawdę, a przekazywane przez pokolenia podania o życiu bogów i ich występkach deprawowały złym przykładem społeczeństwa. Człowiek został oszukany, a ci, którzy rozpowszechnili i utwierdzili tego typu nieprawdziwy zabobon, bardzo często dla własnej korzyści i żądzy, innych przywiedli do upadku i zguby. Dlatego w sposób szczególny za demoralizację i oszustwo są odpowiedzialni ci, którzy przez sztukę, literaturę oraz misteria wykreowali fałszywy świat bogów, a także wypaczyli rzeczywistość prawdziwej religii (Clemens Alexandrinus 55).

Zdaniem Klemensa, jest to w pewien sposób zawinione, gdyż prawda nigdy nie była całkowicie ukryta. Ona ciągle promieniuje swoim światłem, a ludzie są naturalnie ku niej ukierunkowani (Clemens Alexandrinus 133). Potwierdzeniem takiego stanu rzeczy są wybrane dzieła z zakresu literatury oraz filozofii, świadczące o tym, że niektórzy pogańscy mędrcy i poeci ją odnaleźli. Istnieje zatem możliwość dotarcia na drodze intelektualnych poszukiwań do prawdy i doświadczenia jej mocy. Aleksandryjczyk pisał o tym w sposób następujący: „Jeśli więc Grecy przyjęli pewne przebłyski boskiego Słowa i głosili jakąś niewielką część prawdy, to świadczy, że siła tej prawdy nie była ukryta. Z drugiej jednak strony okazali się słabi, ponieważ nie osiągnęli celu" (Clemens Alexandrinus 140).

Klasycznym przykładem filozofa, który dotarł do prawdy, jest Platon (Clemens Alexandrinus 133). Według Klemensa naukę o niej otrzymał od Hebrajczyków, a więc pośrednio na drodze Bożego objawienia. Innym wybitnym mędrcem głoszącym prawdę swoim uczniom był Sokrates. Za teologa, który pisał o prawdziwym Bogu, można również uznać filozofa stoickiego Kleantesa z Assos (Clemens Alexandrinus 136). Zdaniem Aleksandryjczyka, także pitagorejczycy prezentowali poglądy teologiczne bardzo bliskie dogmatom chrześcijańskim. Wszystkie te przykłady świadczą, że dotarcie do prawdy jest możliwe, tym bardziej iż to sam Bóg daje swoje natchnienia i inspiracje wszystkim pragnącym Go poznać (Clemens Alexandrinus 137). 


\section{c) Objawienie Boże}

Najpełniejszym sposobem dotarcia do prawdy jest jednak Boże objawienie. Bóg po upadku człowieka nigdy nie zostawił go bez pomocy. Jemu zawsze zależało na zbawieniu ludzi. Stwórca wiedział, że człowiekowi pogrążonemu w odmętach świata, zniewolonemu przez własną słabość i podstępne zasadzki złego grozi wieczna zguba. Los jego na ziemi przypomina historię Odyseusza powracającego do własnej ojczyzny. Na każdym kroku czai się niebezpieczeństwo: podwodne skały, potworna Charybda oraz syreny, które swym kłamliwym śpiewem wabią żeglarzy ku katastrofie (Clemens Alexandrinus 187). Tym samym są dla człowieka rozkosze świata, przyzwyczajenie do zła oraz dawne życie. Dlatego też posłał Bóg do ludzi swego Syna, odwieczne Słowo, przez które zachęca wszystkich do poznania prawdy (Clemens Alexandrinus 129-130). Chrystus jest Bożym sternikiem, który drogą prawdy, przy współdziałaniu Ducha Świętego, prowadzi tych, którzy Mu się powierzą, do portu zbawienia. Tam zaś, w niebieskiej ojczyźnie: „[...] ujrzysz swego Boga i będziesz dopuszczony do owych świętych misteriów oraz będziesz korzystał z rzeczy zakrytych w niebie a mnie zachowanych, których «ani oko nie widziało [...] ani czyjeś serce nie zdołało pojąć»” (Clemens Alexandrinus 188).

Życie ludzkie bowiem przypomina podróż, w czasie której należy zmienić szlak, gdy dobiega nas wieść, że droga, którą kroczyliśmy do tej pory, wiedzie do zguby (Clemens Alexandrinus 157-158). Wieść ta najpełniej wybrzmiała w objawieniu Bożym. Bóg w swojej dobroci odkrył człowiekowi na nowo prawdę o jego powołaniu do szczęścia. Jego objawienie wpisane jest w całą historię zbawienia. Od najdawniejszych czasów towarzyszył człowiekowi jako Słowo. $Z$ jednej strony mówił do ludzi przez naukę wpisaną w nieśmiertelną duszę, z drugiej zaś objawiał swoją prawdę przez mędrców, proroków i nauczycieli. Do najwybitniejszych z nich należy Mojżesz. On był nie tylko najwyższym arcykapłanem prawdziwego Boga, ale również nauczycielem narodu wybranego. Mojżesz pozostawił po sobie księgi mądrości i święte prawa, które podpowiadają najlepszą drogę ku zbawieniu (Clemens Alexandrinus 143). Nauka Boża oraz proroctwa zapisane w Piśmie św. stanowiły drogowskaz nie tylko dla Izraelitów. Klemens Aleksandryjski uważał, że sam Platon korzystał z nauki Hebrajczyków, podobnie jak Sybilla, której proroctwa prowadziły do kultu jedynego i niewidzialnego Boga. To jednak, co jedynie przeczuwali pogańscy prorocy, o czym śnili filozofowie, zostało objawione przez Jezusa Chrystusa. To w Nim Bóg okazał człowiekowi łaskę zbawienia i pełną prawdę. Jego słowa przewyższają mądrością prawa Solona i Likurga i są cenniejsze od złota i srebra (Clemens Alexandrinus 175). Światło Chrystusa rozbłyska nad wszystkimi narodami i daje prawdziwe życie tym, którzy mu ufają. Oświecenie, które dzięki Niemu dokonuje się w człowieku, sprawia, 
że staje się on święty. Jak orzeł może wpatrywać się w blask słońca, które nie zna swego zachodu (Clemens Alexandrinus 161). Dzięki Niemu człowiek otrzymuje znamię dziecka Bożego oraz staje się przyjacielem Boga na wieki (Clemens Alexandrinus 192).

\section{Podsumowanie}

Klemens Aleksandryjski w Protreptikosie przedstawił tematykę prawdy jako fundamentalną w przepowiadaniu kerygmatycznym. Prawda była bowiem częstym i ważnym tematem podejmowanym przez starożytną myśl grecką. Klemens uczynił z niej płaszczyznę dialogu między światem pogańskim a chrześcijaństwem. Na bazie tej problematyki stworzył swoistą koncepcję poznania prawdy. Według niego ma ona swoje źródło w Bogu i ostatecznie do Niego prowadzi. Nie jest zastrzeżona jedynie dla wybranych, lecz objawia się tym, którzy jej czystym sercem szukają. W Bogu zawarta jest tajemnica prawdy o wszechświecie. To z Jego woli Logos przeobraził i zharmonizował makro- i mikrokosmos. Poznając zatem prawdę Bożą, człowiek ma szansę lepiej poznać świat natury, swoje w nim miejsce oraz powołanie. Prawda ujawnia fałsz kultów pogańskich oraz błędne poglądy filozoficzne. Najpełniejszym jej objawieniem było wcielenie Jezusa Chrystusa. To dzięki Niemu Bóg ukazał swoją łaskę i ,potomków nieba" na nowo wezwał do świata chwały. Prawda pomaga zwyciężyć zło, zmienić dotychczasowe życie oraz ukazuje pokutującym drogę zbawienia. Odkrycie jej związane jest zwykle z procesem nawrócenia, a więc oświeceniem, umocnieniem przez święte misteria oraz opieczętowaniem znamieniem dziecka Bożego. Przez Słowo objawiające prawdę człowiek staje się na nowo obrazem Boga oraz Jego przyjacielem na wieki.

\section{THE TRUTH AS THE FOUNDATION OF THE MISSIONARY PREACHING IN PROTREPTIKOS OF CLEMENT OF ALEXANDRIA}

\section{A B S T R A C T}

Clement of Alexandria ( $† 253)$, one of the most eminent early Christian writers, is the pioneer of a very interesting theological conception of the truth. According to his teaching contained in the work Protreptikos the question of the truth should be the foundation of the preaching mission. The issue of the truth is a platform for dialogue between Christianity and the pagan world. The truth has its source in God and ultimately leads back to Him. In the mystery of God is contained the truth about the 
universe. By getting to know the truth of God man has a chance to get to know the world of nature, his place in it, and his vocation. The truth reveals the falsity of pagan cults and exposes false philosophical views. Its fullest revelation was the incarnation of Jesus Christ. It is thanks to him, that God showed His grace and again called the "descendants of heaven" to eternal glory.

Keywords: Clement of Alexandria; patristic theology; truth; knowledge; early Church

Słowa kluczowe: Klemens z Aleksandrii; teologia patrystyczna; prawda; poznanie; wczesny Kościół

\section{BIBLIOGRAFIA}

Campenhausen, Hans. Ojcowie Kościoła. Tłum. Kazimierz Wierszyłowski. Warszawa: Cykady, 1998.

Clemens Alexandrinus. Protrepticus. Tłum. Claude Mondésert (Sources Chrétiennes 41). Paris: Les Éditions du Cerf, 1949.

Chadwick, Henry. Kościót w epoce wczesnego chrześcijaństwa. Tłum. Andrzej Wypustek. Warszawa: PIW, 2004.

Drączkowski, Franciszek. Kościót-Agape według Klemensa Aleksandryjskiego, Lublin: RW KUL, 1996.

Eusebius Caesariensis. Historia ecclesiastica. Tłum. Gustave Bardy. Vol. 2 (Sources Chrétiennes 41). Paris: Les Éditions du Cerf, 1955.

Judycki, Stanisław. „O klasycznym pojęciu prawdy.” Roczniki Filozoficzne 49.1 (2001): 25-62.

Klemens Aleksandryjski. Zachęta Greków. Tłum. Jan Sołowianiuk (PSP 44). Warszawa: ATK, 1988. 116-201.

Sołowianiuk, Jan. „Klemens Aleksandryjski. Zachęta Greków (Wstęp).” Apologie. Red. Emil Stanula. Pisma Starochrześcijańskich Pisarzy 44. Warszawa: Akademia Teologii Katolickiej, 1988. 99-106.

Wyrwa, Dietmar. „Clemens von Aleksandrien.” Lexikon der antiken christlichen Literatur. Red. Siegmar Döpp i Wilhelm Geerlings. Freiburg: Herder, 2002. 152-154.

Wytzes, Jelle. „Paideia and Pronoia in the Works of Clemens Alexandrinus.” Vigiliae christianae 9 (1955): 146-158.

Żurek, Antoni. Wprowadzenie do Ojców Kościoła. Tarnów: Biblos, 2001.

KSIĄDZ DR JeRzy DUdA, patrolog, wykładowca w WSD im. Jana Pawła II w Siedlcach. Autor wielu prac naukowych i popularnonaukowych z zakresu literatury oraz teologii wczesnochrześcijańskiej, szczególnie środowiska aleksandryjskiego. Wśród nich pozycja książkowa: Jeden świat czy wiele światów? Kosmologiczne podstawy doktryny Orygenesa (Siedlce 2008). Główne kierunki zainteresowań to: soteriologia patrystyczna, egzegeza alegoryczna, teologia Orygenesa, gnoza, schizmy i herezje we wczesnym Kościele. 


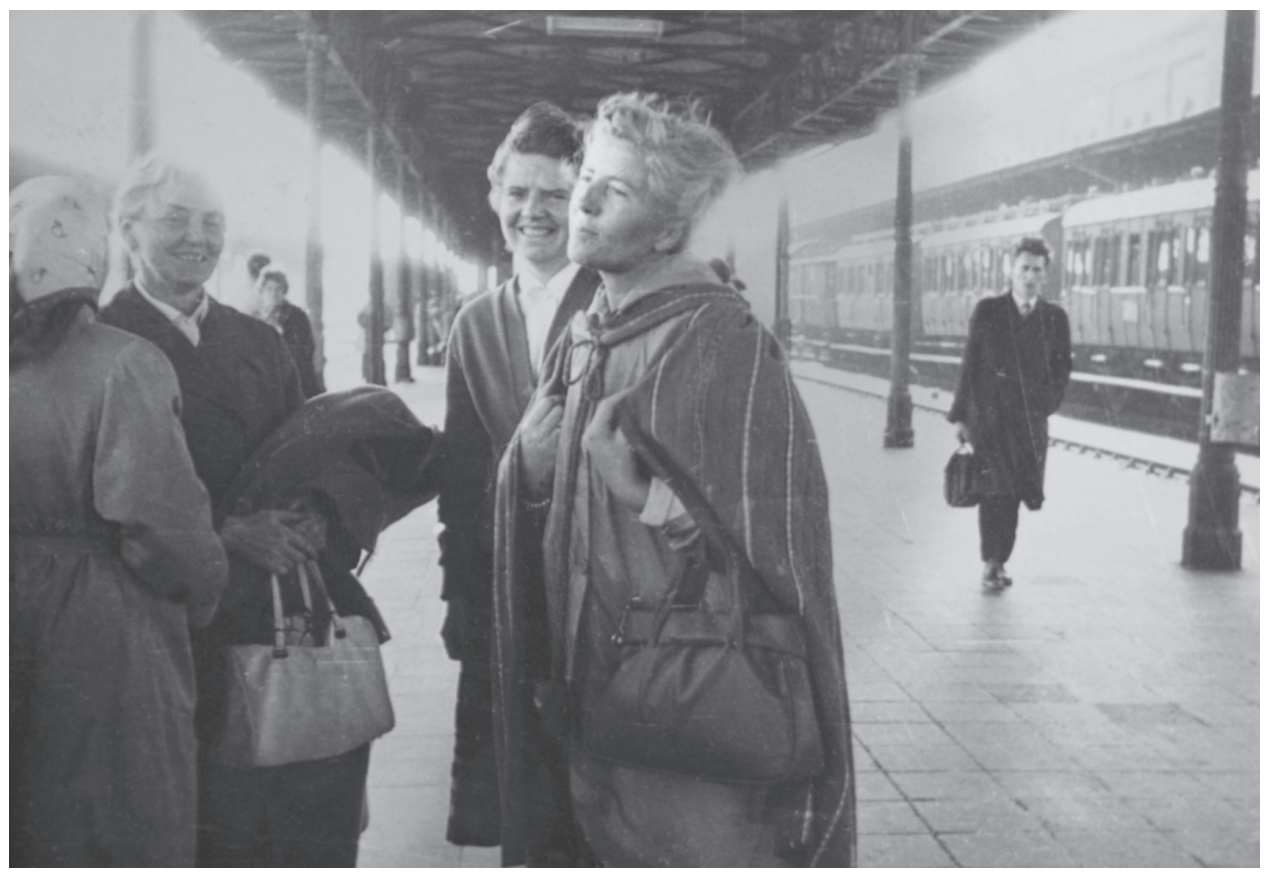

